\title{
Histopathological evaluation of tumours and tumour like lesions of skin and adnexa
}

\author{
Diksha Karki ${ }^{1}$, Abhimanyu $\mathrm{Jha}^{2}$, Shreya Shreevastav ${ }^{2}$, Dinesh B Pokhrel ${ }^{3}$ \\ ${ }^{1}$ Department of Pathology, BP Koirala Institute of Health Science, Dharan, Nepal \\ ${ }^{2}$ Department of Pathology, Tribhuvan University Teaching Hospital, Kathmandu, Nepal \\ ${ }^{3}$ Department of Dermatology, Tribhuvan University Teaching Hospital, Kathmandu, Nepal
}

\author{
Keywords: \\ Adnexa; \\ Skin; \\ Tumours; \\ Tumour like lesions;
}

\begin{abstract}
Background: Tumours and tumour like lesions of skin have overlapping clinical presentation and sometimes pose a diagnostic difficulty on clinical ground alone. Histopathological examination although helpful to arrive at correct diagnosis, at times may be treacherous and may require ancillary tests such as Immunohistochemistry.

Materials and Methods: The study was conducted at Department of Pathology of Tribhuvan University Teaching Hospital. It was a one year prospective study which enrolled 238 cases of skin biopsies after histopathological confirmation of tumours and tumour like lesions. The specimens were processed by standard method and Hematoxylin and Eosin stained sections were examined. Data entry and analysis was done by using SPSS 20 version.

Results: Epidermal cyst was commonest lesion (11.8\%). Among benign tumours squamous papilloma was most frequent while Pilomatricoma and Spiradenoma were most common adnexal tumour. Squamous cell carcinoma constituted $41.8 \%$ and was commonest malignant tumour followed by basal cell carcinoma (30.2\%). Benign tumours were common in 11-30 years of age, malignant tumours in 61-80 years of age while tumour like lesions were common in 21-30 years of age.

Conclusion: Squamous papilloma and squamous cell carcinoma was the most common benign and malignant tumour respectively. Benign adnexal tumours exceeded malignant one and were seen in third decade of life. Epidermal cyst was the commonest tumour like lesions followed by dermoid cysts.
\end{abstract}

\section{Correspondence:}

Dr. Diksha Karki, MBBS, MD

Senior resident/ Lecturer, Department of Pathology

B.P Koirala Institute of Health Science, Dharan, Nepal

ORCID ID: 0000-0002-5399-2029

Email: crystal.diksha701@gmail.com

Received : March 11 2018 ; Accepted : June 21 ${ }^{\text {th }}$ 2018; Published : $1^{\text {th }}$ September 2018

Citation: Karki D, Jha A, Shreevastav S, Pokhrel DB. Histopathological evaluation of tumours and tumour like lesions of skin and adnexa. J Pathol Nep 2018;8:1353-9. DOI: 10.3126/jpn.v\%vi\%i.20873

Copyright: This is an open-access article distributed under the terms of the Creative Commons Attribution 4.0 International License, which permits unrestricted use, distribution, and reproduction in any medium, provided the original author and source are credited.

\section{INTRODUCTION}

A wide range of neoplastic and non-neoplastic disease can develop within skin because of its complexity. ${ }^{1,2}$ The variation in trends and incidence of skin cancer may be due to difference in skin types, geographical distribution, occupational exposure, sun exposure, skin protection measures and difference in disease awareness and surveillance. ${ }^{3}$ Keratinocytic tumours account for approximately $90 \%$ of all skin malignancies, of which, approximately $70 \%$ are basal cell carcinoma (BCC). ${ }^{4}$

Ultraviolet radiation of wave length $280-320 \mathrm{~nm}$ (UVB) and $320-400 \mathrm{~nm}$ (UVA) are implicated in actinic skin damage and carcinogenesis. ${ }^{5}$ UVC $(200-280 \mathrm{~nm})$, although a potent 
Table 1: Age wise distribution of tumour and tumour like lesions

\begin{tabular}{|c|c|c|c|c|}
\hline \multirow{2}{*}{ Age range in years } & \multicolumn{4}{|c|}{ Number of cases (\%) } \\
\hline & Benign neoplasm & Malignant neoplasm & Tumour like lesions & Total \\
\hline$<1$ & $01(00.4)$ & 00.00 & 00.00 & $01(0.4)$ \\
\hline $1-10$ & $09(03.8)$ & $01(0.4)$ & $07(2.9)$ & $17(7.1)$ \\
\hline $11-20$ & $29(12.2)$ & $04(1.7)$ & $14(5.9)$ & $47(19.7)$ \\
\hline $21-30$ & $29(12.2)$ & $03(1.3)$ & $15(6.3)$ & $47(19.7)$ \\
\hline $31-40$ & $21(08.8)$ & $03(1.3)$ & $06(2.5)$ & $30(12.6)$ \\
\hline $41-50$ & $18(07.6)$ & $05(2.1)$ & $04(1.7)$ & $27(11.3)$ \\
\hline $51-60$ & $15(06.3)$ & $03(1.3)$ & $05(2.1)$ & $23(9.7)$ \\
\hline $61-70$ & $09(03.8)$ & $09(3.8)$ & $01(0.4)$ & $19(8.0)$ \\
\hline $71-80$ & $07(02.9)$ & $09(3.8)$ & $01(0.4)$ & $17(7.1)$ \\
\hline $81-90$ & $03(01.3)$ & $03(1.3)$ & 00.00 & $06(2.5)$ \\
\hline $91-100$ & $01(00.4)$ & $03(1.3)$ & 00.00 & $04(1.7)$ \\
\hline Total & $142(60.9)$ & 43 (18.1) & $53(21.0)$ & $238(100)$ \\
\hline
\end{tabular}

mutagen, is not considered significant because it is filtered out by the ozone layer. ${ }^{6}$

Diagnosis of adnexal neoplasms presents unique difficulties, related to the wide pathological variety, substantial frequency of one lesion exhibiting histological features of two or more adnexal lines and the complicated nomenclature. ${ }^{7}$ This prospective study was conducted to estimate the frequency, age, sex and site wise distribution of tumour and tumour like lesions encountered in the department over a period of one year.

\section{MATERIALS AND METHODS}

The study is a hospital based cross sectional prospective study carried out from 1st November 2014 to 31 st October 2015 at Department of Pathology, Maharajgunj Medical Campus, Kathmandu, Nepal. Permission was obtained from ethical review committee prior to the study. The study included all the patients presenting with tumours (benign and malignant) and tumour like lesions arising from skin, adnexa and soft tissue tumour arising from the dermis diagnosed on histopathological examination.

All the diagnosed cases coming for follow up, in which biopsy was done previously, tumours arising from subcutaneous tissue, suboptimal biopsy sample, and tumors and tumor like lesions in the genital region were excluded. All the received skin biopsy specimens were fixed in $10 \%$ formalin and subjected for tissue processing, embedded in paraffin and block was made to obtain 5 micron sections. The sections stained with Hematoxylin and Eosin $(\mathrm{H}$ and E) were examined. The data collection was done in predesigned proforma and data entry was done in SPSS and results were computed using Statistical Package for Social Sciences (SPSS) version 20.

\section{RESULTS}

During the study period, 395 skin biopsies were received, out of which 238 cases were histopathologically diagnosed as tumours and tumour like lesions of skin and adnexa. Tumours and tumour like lesions of skin and adnexa were most commonly seen in 11-30 years $(n=94 ; 39.4 \%)$ of age. (Table 1) Peak of benign neoplasms was seen at 11-30 years $(n=58 ; 24.4 \%)$, thereafter the frequency decreased with increasing age. Malignant neoplasms showed a peak at 61 80 years $(n=18 ; 7.6 \%)$. Before 60 and after 80 years there was not much variation in frequency of tumours. Tumour like lesions showed a peak at third decade of life (Table 1).

There were 135 male and 103 female with M:F ratio of 1.3:1. Male to female ratio for benign tumour, malignant tumour and tumour like lesions were 1.2:1, 1.8:1 and 1.12:1 respectively. (Table 2) The frequency of tumour and tumour like lesions decreased from face to trunk. Sixty seven percent of total benign tumours and $65 \%$ of total malignant tumours occurred in face and scalp. (Table 3).

Basal cell carcinoma was the most common malignant neoplasm in face followed by squamous cell carcinoma and basosquamous carcinoma (fig.1). Squamous cell carcinoma was the most ubiquitous which was seen at almost all the locations. Of 20 cases of benign adnexal tumors, 11 were seen in face and tumours with eccrine and apocrine differentiation was the most common.

Out of 238 cases, tumour constituted 185 cases $(77.8 \%)$ and tumour like lesions constituted 53 cases $(22.2 \%)$. Intradermal melanocytic naevus was the most common tumour followed by SCC and squamous papilloma. Among the tumour like lesions epidermal cysts was most common type followed by dermoid cysts and trichilemmal cysts. Benign neoplasms were the most common lesions $(60 \%)$ followed by tumour like lesions (22\%) and malignant neoplasms (18\%). 
Table 2: Sex wise distribution of tumour and tumour like lesions

\begin{tabular}{llcccc}
\hline \multirow{2}{*}{ S.N } & Gender & \multicolumn{5}{c}{ Number of cases (\%) } \\
\cline { 3 - 6 } & & Benign neoplasm & Malignant neoplasm & Tumour like lesions & Total \\
1. & Male & $79(56)$ & $28(65)$ & $28(53)$ & $135(57)$ \\
2. & Female & $63(44)$ & $15(35)$ & $25(47)$ & $103(43)$ \\
\hline & Total & $\mathbf{1 4 2 ( 1 0 0 )}$ & $\mathbf{4 3 ( 1 0 0 )}$ & $\mathbf{5 3 ( 1 0 0 )}$ & $\mathbf{2 3 8 ( 1 0 0 )}$ \\
\hline
\end{tabular}

Table 3: Site wise distribution of tumour and tumour like lesions

\begin{tabular}{lcccc}
\hline Site & \multicolumn{4}{c}{ Number of cases (\%) } \\
\hline Face & Benign neoplasm & Malignant neoplasm & Tumour like lesions & Total \\
Scalp & $70(49.3)$ & $22(51.1)$ & $31(58.5)$ & $123(51.7)$ \\
Upper Limb & $25(17.6)$ & $06(14.0)$ & $03(05.7)$ & $34(14.3)$ \\
Lower limb & $19(13.4)$ & $04(09.3)$ & $04(07.5)$ & $27(11.3)$ \\
Trunk & $13(09.2)$ & $06(14.0)$ & $04(07.5)$ & $23(9.7)$ \\
Neck & $13(09.2)$ & $04(09.3)$ & $04(07.5)$ & $21(8.8)$ \\
\hline Total & $02(01.4)$ & $01(02.3)$ & $07(13.3)$ & $10(4.2)$ \\
\hline
\end{tabular}

Table 4: Site wise distribution of benign adnexal tumours

\begin{tabular}{|c|c|c|c|}
\hline Site & & Number of cases (\%) & \\
\hline & $\begin{array}{l}\text { Tumour with hair follicle } \\
\text { differentiation }\end{array}$ & $\begin{array}{l}\text { Tumour with eccrine and } \\
\text { apocrine differentiation }\end{array}$ & $\begin{array}{c}\text { Tumour with sebaceous } \\
\text { differentiation }\end{array}$ \\
\hline Face & $4(67)$ & $6(55)$ & $1(33)$ \\
\hline Scalp & $2(33)$ & $2(18)$ & $2(67)$ \\
\hline Upper limb & 00 & $1(09)$ & 00 \\
\hline Lower limb & 00 & $1(09)$ & 00 \\
\hline Trunk & 00 & $1(09)$ & 00 \\
\hline Total & $6(100)$ & $11(100)$ & $3(100)$ \\
\hline
\end{tabular}

Benign soft tissue tumours of dermis were the most common type of benign neoplasms, followed by keratinocytic tumours, melanocytic naevi and adnexal tumours. Out of 50 cases of soft tissue tumour of dermis, vascular tumours were commonest. Out of 20 cases of benign adnexal tumours, pilomatricoma $(2.8 \%)$ and spiradenoma $(2.8 \%)$ were the commonest. Benign vascular neoplasms (total 39 cases) constituted $16.3 \%$ of total biopsies. They constituted $27.5 \%$ of benign neoplasms out of which cavernous hemangioma (36\%) was the most common. (Table 5)

Malignant tumours constituted 18\% (43 cases) of total cases. Keratinocytic tumour was the commonest. Melanoma and adnexal carcinoma constituted three cases each. Squamous cell carcinoma (SCC) was the commonest carcinoma followed by basal cell carcinoma (BCC) Table 6 .

Out of 53 cases ( $22.3 \%$ of total cases) of tumour like lesions, epidermal cysts were the commonest, followed by dermoid cysts and trichilemmal cysts (fig. 2).

\section{DISCUSSION}

Skin biopsy constitutes a simple and inexpensive procedure performed in the dermatology setting which facilitates clinical decisions regarding diagnosis and treatment. Various studies consider histological confirmation as the standard for the correct diagnosis in dermatology.

In the present study skin biopsies constituted $5.4 \%$ of the total surgical pathology specimen which is comparable to the study done by Bari et $\mathrm{al}^{8}$ where skin biopsies constituted $5.38 \%$ of total surgical specimens. Tumours and tumour like lesions of skin constituted $60.2 \%$ of the total skin biopsies in this study.

The present study showed male predominance with male to female ratio of $1.3: 1$. Both benign and malignant tumours were more common in males than females which correlated with the study done by Bari et al. ${ }^{8}$ In the present study $55.6 \%$ of benign neoplasms and $65.1 \%$ of malignant neoplasms were seen in males, whereas $44.3 \%$ of benign neoplasms and $34.8 \%$ of malignant neoplasms were seen in females. Tumour like lesions were also more common in male $(52.8 \%)$ than female $(47.1 \%)$ which correlated with a similar study conducted on tumour like lesions of skin by Bari et al. ${ }^{9}$ As in our study, both benign and malignant skin tumours showed male predominance in a study done 


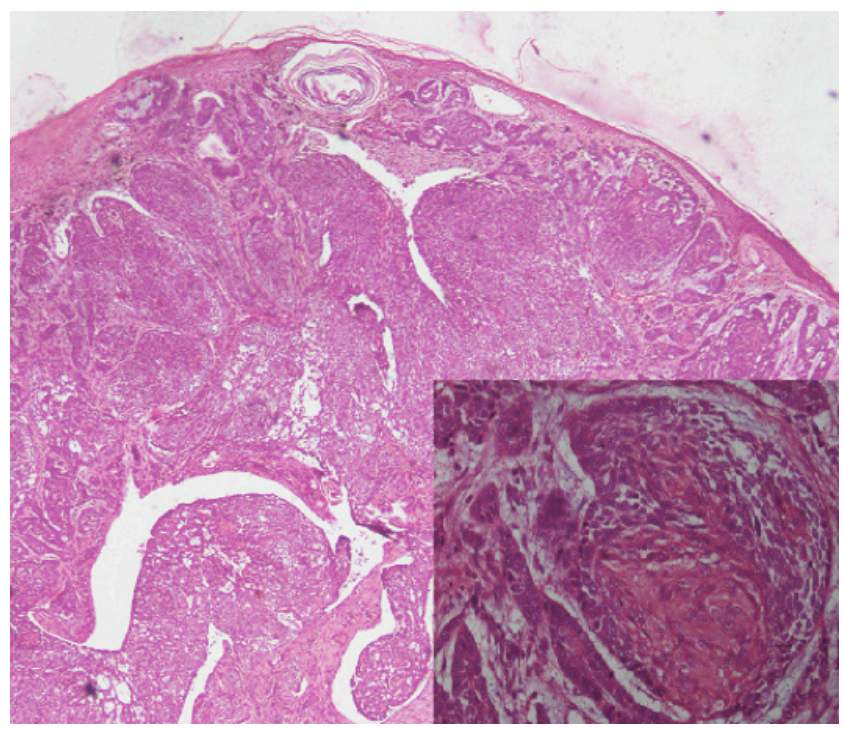

Figure 1: Basosquamous carcinoma (H\&E stain; X400). Inset showing same tumor in high power view.

\section{by Sharma et al. ${ }^{2}$}

In various studies done in Singapore and India, SCC was more common in males than females as in present study. ${ }^{3,10,11}$ All six cases of basosquamous carcinoma, were seen in males. In a study done by Martin et $\mathrm{al}^{12}$, males $(75 \%)$ were more commonly affected than females $(25 \%)$. Out of 18 cases of SCC, 12 cases were seen in males and six cases were seen in females. Hence, the present study showed that frequency of SCC and basosquamous carcinoma in men is higher than in women, which may be attributable to the cumulative effect of sun exposure in males, who work outdoors more commonly than women.

In the present study, benign neoplasms of skin were common in younger age groups (11-30 years) (Table 1). Studies done in India by Nandyal and Puranik ${ }^{13}$ and Bari et $\mathrm{al}^{8}$ showed that benign tumours had a peak incidence in the third decade of life.

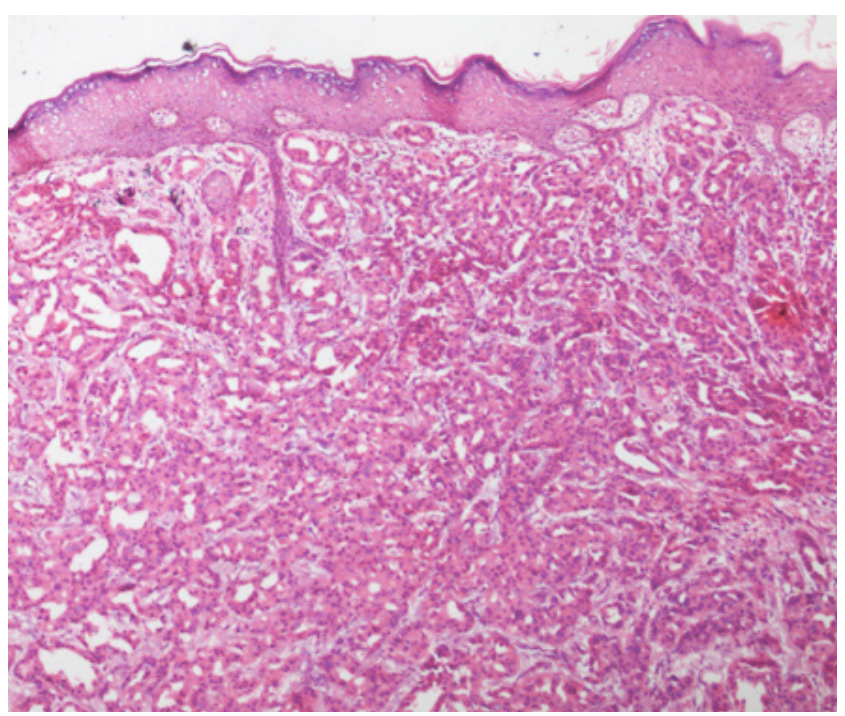

Figure 3: Apocrine carcinoma ((H\&E stain; X400)

It is often observed that the frequency of malignant neoplasm increases with increasing age of the patient. A similar trend was noted in the present study with a peak in seventh to ninth decades of life. Malignant tumours in present study decreased in frequency after 80 years of age. A study done by Gundalli et $\mathrm{a}^{11}$ and Bari et $\mathrm{al}^{8}$ showed that malignant neoplasms were most commonly noted in sixth to eighth decade and seventh decade of life respectively. The age range of different malignant tumours in different studies is compared in table 7 .

In the present study, tumour like lesions were most commonly noted in third decade where as in study done by Bari et $\mathrm{al}^{9}$, maximum cases of tumour like lesions occurred in fourth to fifth decade of life.

In this study, out of 238 cases, benign tumours were most common followed by tumour like lesions of skin and adnexa and malignant tumours which correlated with study of Bari

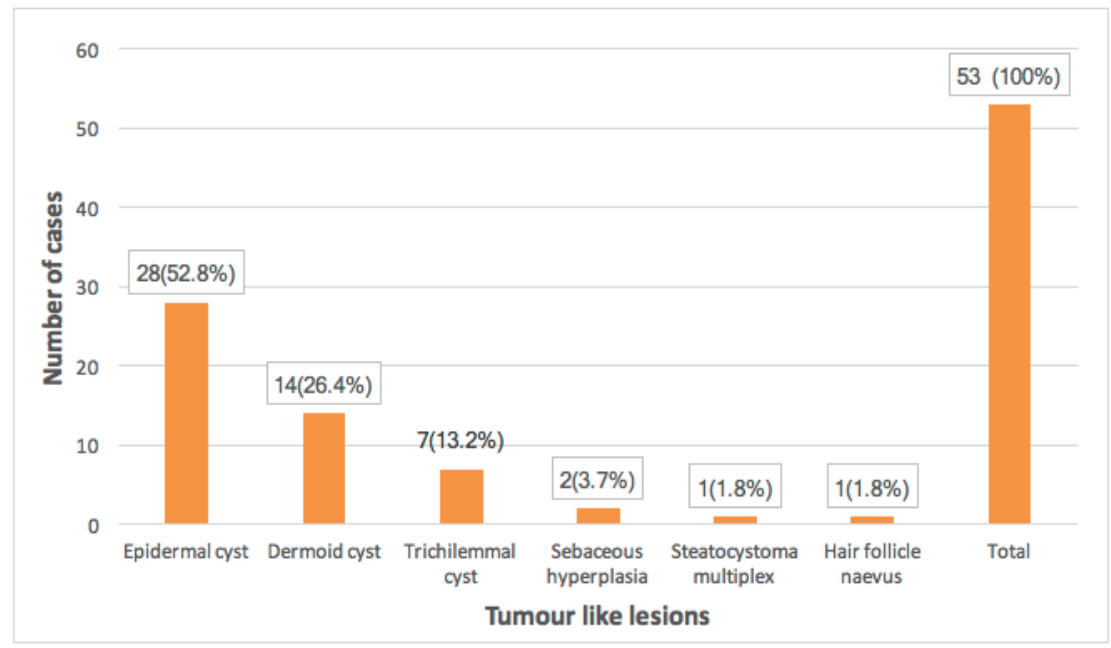

Figure 2: Bar diagram showing frequency of tumour like lesions 


\begin{tabular}{|c|c|c|c|}
\hline S.N. & Benign neoplasms & Number of cases & $(\%)$ \\
\hline \multirow[t]{5}{*}{1.} & Keratinocytic tumours & & \\
\hline & Squamous papilloma & 17 & 11.9 \\
\hline & Seborrhoeic keratosis & 14 & 09.9 \\
\hline & Actinic keratosis & 03 & 02.0 \\
\hline & Keratoacanthoma & 02 & 01.4 \\
\hline \multirow[t]{14}{*}{2.} & Adnexal tumours & & \\
\hline & Hair follicle differentiation & & \\
\hline & Pilomatricoma & 04 & 02.8 \\
\hline & Trichofolliculoma & 01 & 00.7 \\
\hline & Trichilemmoma & 01 & 00.7 \\
\hline & Eccrine and apocrine differen & & \\
\hline & Spiradenoma & 04 & 02.8 \\
\hline & Nodular hidradenoma & 02 & 01.4 \\
\hline & Eccrine hidrocystoma & 02 & 01.4 \\
\hline & Eccrine hidradenoma & 01 & 00.7 \\
\hline & Syringoma & 01 & 00.7 \\
\hline & Cylindroma & 01 & 00.7 \\
\hline & Sebaceous differentiation & & \\
\hline & Naevus sebaceous & 03 & 02.0 \\
\hline \multirow[t]{4}{*}{3.} & Melanocytic naevus & & \\
\hline & Intradermal naevus & 25 & 17.6 \\
\hline & Cellular blue naevus & 03 & 02.0 \\
\hline & Compound naevus & 02 & 01.4 \\
\hline \multirow[t]{2}{*}{4.} & Non- melanocytic naevus & & \\
\hline & Verrucous naevus & 06 & 04.2 \\
\hline \multirow[t]{6}{*}{5.} & Soft tissue tumour of dermis & & \\
\hline & Vascular tumours & 39 & 28.0 \\
\hline & Neurofibroma & 05 & 03.5 \\
\hline & Dermatofibroma & 05 & 03.5 \\
\hline & Sclerotic fibroma & 01 & 00.7 \\
\hline & Total & 142 & 100 \\
\hline
\end{tabular}

et $\mathrm{al}^{8}$ which showed benign tumours were commonest (51.2\%) followed by malignant tumours (48.8\%). In another study done by Gundalli et al ${ }^{11}$ malignant tumours were the most common $(60 \%)$ followed by benign tumours $(40 \%)$ with ratio of malignant to benign being 1:0.6.

Out of 142 cases $(60 \%)$ of benign neoplasms, soft tissue tumour of dermis were commonest followed by keratinocytic tumours. Benign vascular tumours were the most common type of soft tissue tumour of dermis of which cavernous hemangioma (36\%) was commonest. However, in a study done by Margileth and Museles ${ }^{14}$ capillary hemangioma $(81 \%)$ was the most common type of vascular tumour followed by cavernous hemangioma (7\%).

There were 17 cases (11.9\%) of squamous papilloma, which was the commonest benign keratinocytic tumour followed by seborrhoeic keratosis $(9.9 \%)$, actinic keratosis
$(2.1 \%)$ and keratoacanthoma (1.4\%) in the present study. In a study done by Shiva Prasad et a ${ }^{15}$ seborrhoeic keratosis $(57 \%)$ was the commonest benign neoplasms followed by keratoacanthoma (29\%).

Adnexal tumour comprised $10 \%$ of total cases, out of which benign adnexal neoplasms (87.0\%) were more common than malignant adnexal neoplasm (13.0\%). A study by Sharma et $\mathrm{al}^{2}$ also showed that benign adnexal tumours $(80.3 \%)$ were more common than malignant adnexal tumours (19.6\%). The face $(56.5 \%)$ was the commonest site of involvement by adnexal tumour followed by scalp (26.1\%). A similar study by Nair16 in India also showed face to be the commonest site $(76 \%)$ followed by scalp (12.1\%).

In the present study, tumours with eccrine differentiation (7\%) was the commonest benign adnexal neoplasm. Spiradenoma was the commonest eccrine tumour. Tumour 
Table 6: Frequency of malignant tumours of skin and adnexa

\begin{tabular}{|c|c|c|c|}
\hline S.N & Malignant neoplasms & Number of cases & $\%$ \\
\hline \multirow[t]{4}{*}{1} & Keratinocytic tumours & & \\
\hline & Squamous cell carcinoma & 18 & 42.0 \\
\hline & Basal cell carcinoma & 13 & 30.2 \\
\hline & Basosquamous carcinoma & 06 & 14.0 \\
\hline 2 & Melanoma & 03 & 06.9 \\
\hline \multirow[t]{5}{*}{3.} & Adnexal tumours & & \\
\hline & Apocrine carcinoma & 01 & 02.3 \\
\hline & Microcystic adnexal carcinoma & 01 & 02.3 \\
\hline & Sebaceous carcinoma & 01 & 02.3 \\
\hline & Total & 43 & 100 \\
\hline
\end{tabular}

Table 7: Comparison of age range of different malignant tumours in various studies

\begin{tabular}{lllcr}
\hline & & \multicolumn{3}{c}{ Age in years } \\
S.N & Authors & SCC & BCC & Melanoma \\
\hline 1. & Bari et al $^{8}$ & $61-70$ & $61-70$ & $51-60$ \\
2. & Adinarayan and Krishnamurthy $^{10}$ & $41-60$ & $61-80$ & - \\
3. & Gundalli et al $^{11}$ & $60-69$ & $60-69$ & $60-69$ \\
4. & Present study & $61-70$ & $71-80$ & $61-80$
\end{tabular}

Table 8: Comparative frequency of different malignant tumour of skin in various studies

\begin{tabular}{|c|c|c|c|c|c|c|}
\hline \multirow[b]{2}{*}{ S.N } & \multirow[b]{2}{*}{ Authors } & \multicolumn{5}{|c|}{ Different malignant tumours } \\
\hline & & SCC & BCC & BSC & Melanoma & $\begin{array}{c}\text { Malignant adnexal } \\
\text { Tumor }\end{array}$ \\
\hline 1. & 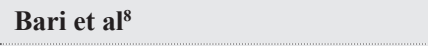 & $45.9 \%$ & $34.4 \%$ & & $4.9 \%$ & $8.2 \%$ \\
\hline 2. & Gundalli et al ${ }^{11}$ & $28.0 \%$ & $16.0 \%$ & & $8.0 \%$ & $5.0 \%$ \\
\hline 3. & Adinarayan and Krishnamurthy ${ }^{10}$ & $83.9 \%$ & $13.1 \%$ & & & \\
\hline 4. & Hajheydari et al ${ }^{19}$ & $23.0 \%$ & $68.4 \%$ & & $3.0 \%$ & \\
\hline 5. & Bhudraja SN et al ${ }^{18}$ & $49.0 \%$ & $17.6 \%$ & & $29.4 \%$ & $0.9 \%$ \\
\hline 6. & Present study & $41.8 \%$ & $30.2 \%$ & $13.9 \%$ & $6.9 \%$ & $6.9 \%$ \\
\hline
\end{tabular}

with hair follicle differentiation followed the eccrine tumours (Table 5), which is similar to study by Nair ${ }^{16}$ where eccrine differentiation constituted the maximum cases $(52 \%)$ followed by tumours with hair follicle differentiation $(36.3 \%)$.

In the present study there were three cases of malignant adnexal tumours $(6.9 \%$ of total malignant tumours), with one case each of apocrine carcinoma (fig.3), microcystic adnexal carcinoma and sebaceous carcinoma.

The present study showed benign melanocytic lesions $(21 \%)$ with intradermal nevus being the commonest, far exceeding melanoma $(6.9 \%)$, which correlated with the study done by Suvernakar et $\mathrm{al}^{17}$ where benign melanocytic naevi $(27.27 \%)$ exceeded the cases of melanoma (11.36\%).

In the present study, malignant neoplasm constituted $18 \%$ of total cases (43 cases out of total 238 cases), of which malignant keratinocytic tumour were the commonest followed by three cases each of melanoma and malignant adnexal tumour.The finding in this study was similar to four studies done in India by Bari et al, ${ }^{8}$ Adinarayan and Krishnamurthy, ${ }^{10}$ Gundalli et al, ${ }^{11}$ Bhudraja SN et al. ${ }^{18}$ However, in a similar study by Hajheydari et $\mathrm{al}^{19}$ in Iran, BCC $(68.4 \%)$ exceeded SCC (23\%), followed by melanoma $(3.3 \%)$. The frequencies of different malignant tumours in different studies are compared in Table 8.

In present study, out of total number of cases, six cases of SCC and nine cases of BCC were noted on face. In a similar study done in Iran by Hajheydari ${ }^{19}$, head and neck was the most common site of involvement by SCC (49\%) and BCC (93\%). The reason for common involvement of face by these tumours could be due to actinic exposure.

Tumour like lesions of skin and adnexa constituted 53 cases of total surgical biopsies $(0.7 \%$ of total 7275 cases $)$. 
A similar study done by Bari et al9 showed that tumour like lesions of skin constituted 175 cases $(1.9 \%$ of total 9100 surgical biopsy specimen). Epidermal cyst was the commonest (52.8\%) tumour like lesion followed by dermoid cyst $(26.4 \%)$ in present study which correlated with study by Bari et al. ${ }^{9}$

\section{CONCLUSION}

Biopsies for tumours and tumour like lesions of skin and adnexa constituted the majority of skin biopsies. Frequency of skin biopsies for tumour and tumour like lesions was at 11-30 year of age groups. Face was the most common location for such lesions. Benign neoplasms outnumbered the malignant neoplasms. Tumour like lesions are clinically diagnosed by their presentation. However, early biopsy would help in rulling out any possibilities of malignancies.

\section{Conflict of Interest: None}

\section{REFERENCES}

1. McGrath JA, Uitto J. Anatomy and Organization of Human Skin. In: Burns T, Breathnach A, Cox N, Griffiths C, editor. Rook's Textbook of Dermatology. 8th ed. UK: Wiley-Black Well; 2010. p3.1-3.52. Crossref

2. Sharma A, Paricharak DG, Nigam JS, et al. Histopathological study of skin adnexal tumours- Institutional study in South India. Journal of skin cancer. Article ID 543756, 4 pages, 2014. Crossref

3. Koh D, Wang H, Lee J, Chia KS, Lee HP, Goh CL. Basal cell carcinoma, squamous cell carcinoma and melanoma of the skin: Analysis of the Singapore Cancer Registry data 1968-97. Br J Dermatol. 2003;148:1161-6. Crossref

4. Weedon D, Marks R, Kao GF, Harwood CA. Keratinocytic tumours. In: LeBoit PE, Burg G, Weedon D, Sarasin A, editor. World Health Organization of Tumours: Pathology and Genetics of Skin Tumours. Lyon, France: International Agency for Research on Cancer (IARC) Press; 2006. p.10-2.

5. Green A, Whiteman D, Frost C, Battistutta D. Sun exposure, skin cancers and related skin conditions. J Epidemiol 1999;9:7-13. Crossref
6. Neoplasia. In: Kumar V, Abbas AK, Aster JC. Robbins and Cotran Pathologic basis of disease.9th ed: Elsevier Saunders; 2014. p. 265340.

7. Ahmed TSS, Priore JD, Seykora JT. Tumors of epidermal appendages. In: Elder DE, editor. Lever's histopathology of skin. 10th ed: Wolters Kluwer health/ Lippincott Williams and Wilkins; 2005. p. 851909.

8. Bari V, Murarkar P, Gosavi A, Sulhyan K. Skin TumoursHistopathological Review of 125 Cases. Indian Medical Gazette. 2014:418-27.

9. Bari V, Murarkar P, Gosavi A, Sulhyan K. Tumour like Lesions of Skin - A clinicopathological analysis of 175 Cases. Indian Medical Gazette. 2014:129-33.

10. Adinarayan M, Krishnamurthy SP. Clinicopathological evaluation of nonmelanoma skin cancer. Indian journal of dermatology. 2011;56:670-2. Crossref

11. Gundalli S, Kolekar R, Pai K, Kolekar A. Histopathological Study of Skin Tumours. International Journal of Healthcare Sciences 2015;2:155-63.

12. Martin RCG, Edwards MJ, Cawte TG, Sewell CL, McMasters KM. Basosquamous carcinoma, analysis of prognostic factors influencing recurrence. Cancer. 2000;88:1365-9. Crossref

13. Nandyal SS, Puranik RB. Study of demographic profile of skin tumors in a tertiary care hospital. IJCRR 2014;6:24-8.

14. Margileth AM, Museles M. Cutaneous Hemangiomas in Children. Diagnosis and conservative management. JAMA 1965;194:523-6. Crossref

15. Shivaprasad PN, Pranhu MH, Ahmed SS, Begum A. Benign Tumors of Skin. GJMR: Microbiology and Pathology. 2014;14:11-4.

16. Nair PS. A clinicopathologic study of skin appendageal tumors. Indian J Dermatol Venereol Leprol 2008;74:550. Crossref

17. Suvernakar SV, Harwani SR, Deshpande SA. Clinicopathological study of pigmented skin lesions.IOSR-JDMS 2014;13:70-3. Crossref

18. Budhraja SN, Pillai VC, Periyanayagam WJ, Kaushik SP, Bedi BM. Malignant neoplasms of the skin in Pondicherry(a study of 102 cases). Indian Journal of Cancer. 1972;9:284-95. Crossref

19. Hajheydari Z, Golpour M, Ghasemi M. A clinicopathologic reveiw of skin cancers in Sari in north-east of Iran (1996-2006). The Internet Journal of Epidemiology. 2006;5:1-4. 